\title{
Serological Study of Hepatitus B Virus (HBV), Hepatitus C Virus (HCV) in Blood Collection Centers
}

\author{
Bushra Bibi ${ }^{1}$, Anwar Ali ${ }^{2}$, Imran Khan ${ }^{3}$, Kausar Saeed ${ }^{4}$, Sumaya Amin ${ }^{1}$ and Muzafar Shah ${ }^{1 *}$ \\ ${ }^{1}$ Centre for Animal Sciences \& Fisheries, University of Swat, Pakistan \\ ${ }^{2}$ Department of Biochemistry, Saidu Medical College, Saidu Sharif Swat, Pakistan \\ ${ }^{3}$ Department of Physiology, Saidu Medical College, Saidu Sharif Swat, Pakistan \\ ${ }^{4}$ Department of Zoology, University of Buner, Pakistan \\ *Corresponding author: Muzafar Shah, Centre for Animal Sciences \& Fisheries, University of Swat, Pakistan
}

\section{ARTICLE INFO}

Received: 幽 April 01, 2021

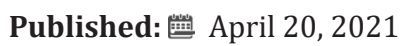

Citation: Bushra Bibi, Sumaya Amin, Anwar Ali, Imran Khan, Muzafar Shah. Serological Study of Hepatitus B Virus (HBV), Hepatitus C Virus (HCV) in Blood Collection Centers. Biomed J Sci \& Tech Res 35(2)-2021. BJSTR. MS.ID.005664.

Abbreviations: HBV: Hepatitis B Virus; HBV: Hepatitis C Virus; EIA: Enzyme Immunoassays; HCC: Hepatocellular Carcinoma; EIA: Enzyme Immunoassays; CIA: Chemiluminescence Immunoassay; IDU: Intravenous Drug Use

Keywords: Hepatitis B Virus; Hepatitis C Virus; Diagnostic Procedure; Swat Valley

\begin{abstract}
The present study was carried out in District Swat, from July to December, 2020, to find out prevalence of Hepatitis B virus (HBV), Hepatitis C virus (HBV) in Human blood donors. For this purpose, a total 1292 data were collected from blood doners units in Swat i.e Al-Fajar Foundation, Frontier Foundation, Saidu Group of Teaching Hospital and casualty lab of Central Hospital, which were recommended for diagnosis of Hepatitis $B$ virus, Hepatitis C virus (HCV) and Blood grouping in Human blood donors by using different diagnostic test ie. Blood tests, Liver ultrasound, Liver biopsy, Hepatitis B panel of blood tests for diagnosis of HBV. HCV antibody test, Serologic Antibody Assays, Enzyme immunoassays (EIA), Ora Quick Rapid Antibody test, Molecular HCV RNA Tests were used for diagnosis of HCV. ABO typing for determination of blood grouping. In 1292 blood samples which were examined, in which $3.40 \%$ blood samples test were positive with frequency $2.08 \%$ test were positive for Hepatitis C virus and $1.31 \%$ for Hepatitis B virus. This study concluded less prevalence of HBV and HCV in blood donors but more extensive seroprevalance and frequency studies of the general population are needed to determine the true prevalence of these diseased markers. For determination of blood grouping, 65 blood samples from blood donors were collected from Al- Fajar foundation and Frontier Foundation, in which $21.53 \%$ were $0+, 32.30 \%$ were $\mathrm{A}+, 32.30 \%$ were $\mathrm{B}+$, $3.0 \%$ were $\mathrm{B}-, 1.5 \%$ were $\mathrm{AB}$ - and $9.2 \%$ were $\mathrm{AB}+$ blood groups and 0 - and $\mathrm{A}$ - blood groups were not determined.
\end{abstract}

\section{Introduction}

Hepatitis B virus (HBV) is an important human pathogen that cause chronic infections throughout the world and it is spread by mucosal and percutaneous exposure to infected blood and also through other body fluid [1]. Hepatitis B virus caused deadly liver infection called Hepatitis B. In all five types of Hepatitis, Hepatitis $\mathrm{B}$ is most dangerous because it is clinically asymptomatic [2]. Hepatitis B virus belongs to a family known as Hepa dna viridae. HBV is a small virus and is enveloped virus with double stranded DNA genome and its size is 3.2 kilo base pair [3]. HBV infects hepatocytes and can results in many liver complication e.g. liver cirrhosis, hepatocellular carcinoma (HCC), and other severe liver diseases [4]. HBV can be transmitted/spread by use of unsterilized instrument, tattooing, blood transfusion, drugs abuse. Working in a healthcare setting, dialysis, acupuncture, tattooing, sharing razors or toothbrushes with an infected person are also risk factor for developing HBV infection [5]. Medicine used to treat infections of HBV are Adefovir, Entecavir [6]. These both medicines proves to be an emerging drugs against HBV infection [7]. HBV on the basis of sequence comparison is classified into eight genotypes, A to $\mathrm{H}$ and each genotype has distinct geographic distribution [8]. The prevalence of HBV was reported highest in Western Pacific Region adult population i.e. $6.2 \%$ and it was also reported high in African Region i.e. 6.1\% [9]. The prevalence rate of HBV in Pakistan as high as $3 \%[10]$. 
In low economic status people in Pakistan, the prevalence of HBV is high. As $67.5 \%$ people of Pakistan belong to rural areas and have low economic status, so in this way it is very necessary to control HBV [11]. The prevalence of HBV in general population in Pakistan is about $3-5 \%$ and $10-20 \%$ in population at high risk [10]. In Baluchistan, the prevalence rate of HBV is 9.3\%, followed by $2.4 \%($ Punjab), $2.3 \%$ (Sindh) and $1.31 \%$ ( KP). And the lowest rate of HBV $1.1 \%$ is reported in Khyber Pakhtunkhwa [12]. HCV is a virus which causes hepatitis $\mathrm{C}$ which is a chronic disease and it infects liver of a person. HCV was discovered in 1989 [13], and the number of acute HCV cases has fallen by more than $80 \%$ [14]. HCV is RNA virus and it is positive single-stranded RNA enveloped viruses which belong to family Flaviviridae and Genus Hepacivirus. HCV shape is icosahedral and its diameter is 56-65 and approximately 9.6kb long genome size [15]. Hepatitis C virus (HCV) is body fluid-borne hepatotropic viruses and it results in long-lasting liver diseases, cirrhosis and death [16]. Test used for detection of HCV are Serologic antibody assays [13], Enzyme immunoassays (EIA) [17], Chemiluminescence Immunoassay (CIA) [18], Ora Quick Rapid Antibody Test [19]. In the past two decades, a decline in the prevalence of HCV infection occur in the United States, [20], Western and Northern Europe [21] and Australia [22]. But this disease is continuously on rise in lesser developed and developing countries. In developing countries there is lack of awareness, inadequate blood screening facilities, nosocomial transmission and a lack of effective treatments so these problems rise HCV infection [23].

The prevalence of HCV varies i.e. in Western Europe, the Americas and Australia about $2 \%$ of total population is infected with HCV [23]. According to some reports, in Pakistan about 6\% of total population is infected with hepatitis C virus [24]. In Punjab the prevalence rate of $\mathrm{HCV}$ is $6.7 \%$, in Sindh HCV prevalence is $5 \%$, in Baluchistan prevalence rate of HCV is $1.5 \%$ and the lowest rate is reported in Khyber Pakhtunkhwa which is 1.1\% [25]. For high prevalence of HBV and HCV, different risk factors are responsible such as Intravenous Drug Use (IDU), blood transfusion which is not screened, sex with infected person, tattooing and use of infected syringes [26]. The term blood group refers to entire blood group system. Blood group system consist of red blood cells antigens and its specificity is controlled by series of genes and Blood type refers to a specific pattern of reaction to testing antisera within a given system. In 1900, Karl Landsteiner discovered ABO blood group system [27]. In 1941, Rh blood group system were explained by Landsteiner and Wiener [28]. The blood groups can be determined by the presence or absence of the inherited antigen present on the red blood cell which is determined by specific antibodies [29]. On the basis of presence and absence of $A$ and $B$ surface antigens, there are 4 types of $\mathrm{ABO}$ blood group i.e. $\mathrm{A}, \mathrm{B}, \mathrm{O}$ and $\mathrm{AB}$ and the frequencies of the four $\mathrm{ABO}$ blood groups vary from each other all over the world [30]. At present there are about 400 antigens discovered which is associated with erythrocytes [31] and as Mendelian traits, these are transmitted to next generation [32]. Among which the ABO and $\mathrm{Rh}$ are the major blood group antigens [33]. The ABO blood group system and Rh blood group system have proved important not only in transfusion-related problems but also specific disease association with RBC surface antigens (Owen, 2000) [27].

\section{Method and Materials}

\section{Study Area}

The present study was carried out at district Swat, Khyber Pakhtunkhwa. It lies between $34^{\circ}-40^{\prime}$ to $35^{\circ} \mathrm{N}$ latitude and $72^{\prime}$ to $74^{\circ}-6^{\prime}$ E longitude and is located between the foothills of Hindu Kush mountain range, to its north Gilgit and Chitral is located, to the south Mardan is located, to the west Dir is located, while from Hazara it is isolated by Indus in the east. Swat lies in the region where South Asia, Central Asia and China meet so its location has a major strategic importance (Figure 1).

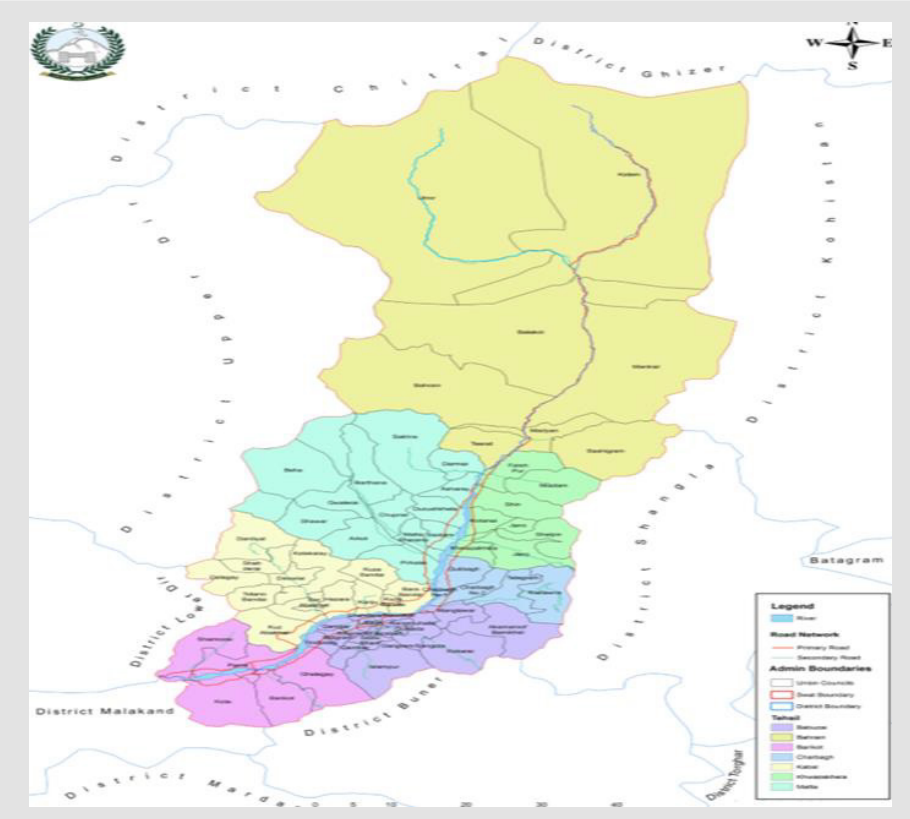

Figure 1: Study area district Swat, Khyber Pakhtunkhwa, Pakistan. 


\section{Data Collection}

For the current study the data were collected from patients visiting the hospital i.e. Saidu group of teaching hospital Saidu Sharif Swat and Central hospital casualty lab showing symptoms for hepatitis B virus and hepatitis $\mathrm{C}$ virus and data were also collected from Al-Fajar foundation and frontier foundation among human

\section{Data Analysis}

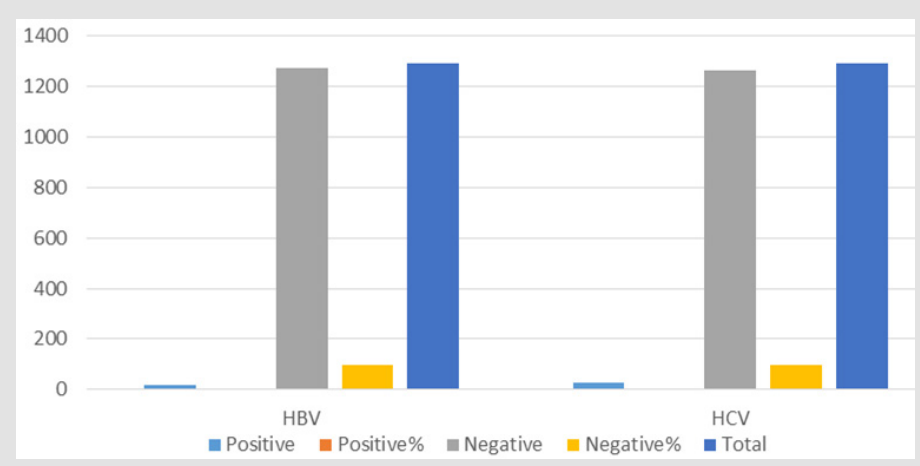

Figure 2: Percentage of prevalence of $\mathrm{HBV}$ and $\mathrm{HCV}$ in the study area.

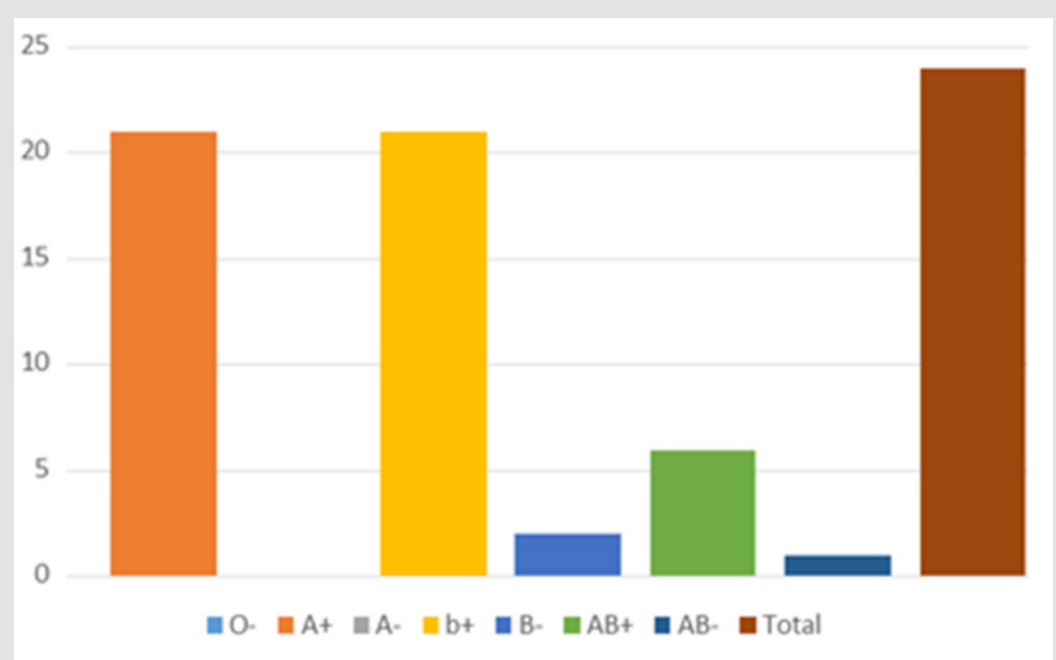

Figure 3: ABO blood grouping.

The data was elevated through charts and Microsoft excel windows version 2013. All the results were given in the forms of rates (\%) (Figures $2 \& 3$ ).

\section{Results}

A total of 1292 blood samples were examined by Al- Fajar foundation, Frontier Foundation, Saidu group of teaching hospital and Central hospital casualty lab for diagnosis of Hepatitis B Table 1: Prevalence of HBV and HCV in Swat valley. blood donors in university of Swat main campus.

\section{Sample Size}

A total of 1292 samples were collected in which, 24 were examined by Al- Fajar foundation, 41 were examined by Frontier Foundation, 1057 were examined by Saidu group of teaching hospital and 170 were examined by Central hospital casualty lab. 
Table 2: Prevalence of HBV and HCV in Swat valley.

\begin{tabular}{|c|c|c|c|c|c|c|c|c|c|}
\hline \multicolumn{10}{|c|}{ Blood Grouping } \\
\hline Blood Groups & $\mathrm{O}+$ & $\mathrm{O}-$ & $\mathrm{A}+$ & $\mathrm{A}-$ & $\mathrm{B}+$ & $\mathrm{B}-$ & $\mathrm{AB}+$ & $\mathrm{AB}-$ & Total \\
\hline Frequencies & 14 & 0 & 21 & 0 & 21 & 2 & 6 & 1 & 65 \\
\hline
\end{tabular}

\section{Discussion}

The current study was conducted to find out prevalence of Hepatitis B virus, Hepatitis C virus and blood grouping in swat valley from July to December, 2020. Hepatitis B is one of the most common infectious disease globally and it is estimated that there are 350 million chronic hepatitis B virus worldwide. The prevalence of chronic HBV infection varies geographically from high $(>8 \%)$, intermediate $(2-7 \%)$ to low $(<2 \%)$ prevalence. More than 170 million persons have hepatitis $C$ virus (HCV) infection worldwide. The Eastern Mediterranean region and Europe have the highest prevalence $(2.3 \%$ and $1.5 \%$, respectively), with other regions having an estimated prevalence of 0.5\%-1.0\%.Jeddah City, Saudi Arabia, has a reported HCV prevalence of $0.38 \%$. In this current study a total of 1292 blood samples were examined by Al- Fajar foundation, Frontier Foundation, Saidu group of teaching hospital and Central hospital casualty lab for diagnosis of Hepatitis
B virus and Hepatitis C virus, in which 44 blood samples test were positive such as $27(2.08 \%)$ test were positive for Hepatitis C virus and 17 (1.31\%) for Hepatitis B virus. This study was also supported by study proposed in South Gondar District blood Bank, Northwest Ethiopia [34] which reported prevalence of HBV, and HCV 5.8\% and 4.2\%. A similar study was carried out in 2013 to determine the prevalence of HCV and HBV among blood donors at Hyderabad, Pakistan, showed prevalence of HCV (3.45\%) and HBV (1.82\%) [35]. Another study was conducted to determine the prevalence of transfusion-transmitted infections i.e., Hepatitis B, Hepatitis C, Human immunodeficiency viruses, Syphilis and Malaria in blood donors of Pakistan, out 16,602 blood donors which were taken 16,557 were males and 45 females. Out of total samples the prevalence of Hepatitis B, Hepatitis C, Human immunodeficiency viruses, Syphilis and Malaria was found to be 1.84, 1.7, 0.04, 2.1 and $0.07 \%$ [36] (Tables 3-8).

Table 3: HBV and HCV prevalence (Al- Fajar Foundation).

\begin{tabular}{|c|c|c|c|c|c|}
\hline Parameters & Positive & Positive $\%$ & Negative & Negative $\%$ & Total \\
\hline HBV & 0 & 0 & 24 & 100 & 24 \\
\hline HCV & 0 & 0 & 24 & 100 & 24 \\
\hline
\end{tabular}

Table 4: Blood grouping (Al- Fajar Foundation).

\begin{tabular}{|c|c|c|c|c|c|c|c|c|c|}
\hline \multicolumn{1}{|c|}{ Blood Grouping } & $\mathrm{A}-$ & $\mathrm{B}+$ & $\mathrm{B}-$ & $\mathrm{AB}+$ & $\mathrm{AB}-$ & Total \\
\hline Blood Groups & $\mathrm{O}+$ & $\mathrm{O}-$ & $\mathrm{A}+$ & $\mathrm{A}-$ & 0 & 0 & 0 & 0 & 24 \\
\hline Frequencies & 7 & 1 & 7 & 0 & 9 & 0 & \\
\hline
\end{tabular}

Table 5: HBV and HCV prevalence (Frontier Foundation).

\begin{tabular}{|c|c|c|c|c|c|}
\hline Parameters & Positive & Positive\% & Negative & Negative\% & Total \\
\hline HBV & 1 & 2.5 & 40 & 97.56 & 41 \\
\hline HCV & 0 & 0 & 41 & 100 & 41 \\
\hline
\end{tabular}

Table 6: Blood grouping (Frontier Foundation).

\begin{tabular}{|c|c|c|c|c|c|c|c|c|c|}
\hline \multicolumn{10}{|c|}{ Blood Grouping } \\
\hline Blood Groups & $0+$ & $0-$ & $\mathrm{A}+$ & A- & $\mathrm{B}+$ & B- & $\mathrm{AB}+$ & $\mathrm{AB}-$ & Total \\
\hline Frequencies & 7 & 0 & 13 & 0 & 12 & 2 & 6 & 1 & 41 \\
\hline
\end{tabular}

Table 7: Prevalence of HBV and HCV in Swat valley (Saidu group of teaching hospital).

\begin{tabular}{|c|c|c|c|c|c|}
\hline Parameters & Positive & Positive $\%$ & Negative & Negative\% & Total \\
\hline HBV & 16 & 1.51 & 1041 & 98.4 & 1057 \\
\hline HCV & 23 & 2.17 & 1034 & 97.8 & 1057 \\
\hline
\end{tabular}

Table 8: Prevalence of HBV and HCV in Swat valley (Center hospital casualty Lab).

\begin{tabular}{|c|c|c|c|c|c|}
\hline Parameters & Positive & Positive $\%$ & Negative & Negative $\%$ & Total \\
\hline HBV & 0 & 0 & 170 & 100 & 170 \\
\hline HCV & 4 & 2.3 & 166 & 97.64 & 170 \\
\hline
\end{tabular}


In our current study, out of 65 blood samples from blood donors which were collected from Al- Fajar foundation and Frontier Foundation, 14 (21.53\%) were 0+, 21 (32.30\%) were A+, $21(32.30 \%)$ were $\mathrm{B}+, 2$ (3.0\%) were B-, $1(1.5 \%)$ were $\mathrm{AB}$ - and 6 $(9.2 \%)$ were $A B+$ blood groups and 0 - and $A$ - blood groups were not determined. A similar study was conducted to determine the distribution pattern of the ABO and Rh blood groups among blood donors in Kumaon region of Uttarakhand. But this study results do not match with our study results. This study were carried out at blood bank of Shushila Tewari Hospital of Government Medical College, Haldwani. In this study total 12701 blood donor's samples were taken and $\mathrm{ABO}$ and $\mathrm{Rh}$ typing was conducted using slide agglutination method with antisera $\mathrm{ABO}$ and $\mathrm{Rh}$. The results of this study shows that most common blood group was B (32.07\%) and least common being $\mathrm{AB}(10.53 \%)$ and Blood group ' $\mathrm{O}$ ' and ' $\mathrm{A}$ ' had same frequency. In our study most common blood group is $\mathrm{A}+, \mathrm{B}+$ and $\mathrm{O}$ - and $\mathrm{B}$ - were not determined. Another study was conducted to find out the frequency of $\mathrm{ABO}$ and Rhesus blood groups in blood donors and this study was done in Lahore, Pakistan. In this study Total 3000 samples were taken and out of the total 3000 samples the most frequent $\mathrm{ABO}$ blood group was $\mathrm{B}$ which was (37.8\%), O blood group was (28.8\%), A blood group was (24.2\%) and $A B$ blood group was $(9.1 \%)$ in blood donor. In Rhesus system $93.0 \%$ were $\mathrm{Rh}+$ ve and $7.0 \%$ were. Rh-ve. Such types of studies help in management of blood banks and transfusion services [37,38].

\section{Conclusion}

In the current study, a total of 1292 blood samples were examined by Al- Fajar foundation, Frontier Foundation, Saidu group of teaching hospital and Central hospital casualty lab for diagnosis of Hepatitis B virus and Hepatitis C virus, in which 44 blood samples test were positive such as 27 test were positive for Hepatitis $C$ virus and 17 for Hepatitis B virus. This study concluded less prevalence of HBV and HCV in blood donors but more extensive seroprevalance and frequency studies of the general population are needed to determine the true prevalence of these diseased markers. In our study out of 65 blood samples from blood donors which were collected from Al- Fajar foundation and Frontier Foundation, 14 (21.53\%) were $0+, 21(32.30 \%)$ were $A+, 21$ (32. 30\%) were $B+, 2$ (3.0\%) were B-, 1 (1.5\%) were AB- and 6 (9.2\%) were AB+ blood groups and $\mathrm{O}$ - and $\mathrm{A}$ - blood groups were not determined. From this study it were concluded that most common blood group in Swat valley is $\mathrm{A}+$ and $\mathrm{B}+$.

\section{Acknowledgement}

I would like to thanks of gratitude to Al- Fajar Foundation, Frontier Foundation, Saidu Group of Teaching Hospital and Casualty lab of Central hospital for their facilities.

\section{References}

1. Ott JJ, Steven GA, Gregor J, Weirsma ST (2012) Global epidemiology of hepatitis B virus infection: New estimates of age-specific HBsAg seroprevalence and endemicity. Vaccine 30(12): 2212-2019.

2. Khan MY (2017) Ratio of Hepatitis B and Hepatitis C viral infection in pregnant women of Haripur KPK, Pakistan. Bio Medicine and Surgery 1(2): $73-76$.

3. Seeger Christoph, Mason WS (2015) Molecular biology of hepatitis B virus infection. Virology 479-480: 672-686.

4. Bernal W, Auzinger G, Dhawan A, Wendon J (2010) Acute liver failure. Lancet 376(9736): 190-201.

5. Liaw YF, Chu CM (2009) Hepatitis B virus infection. Lancet 373(9663): 582-592.

6. Van Bömmel F, Wünsche T, Mauss S, Petra Reinke, Alexandra Bergk, et al. (2004) Comparison of adefovir and tenofovir in the treatment of lamivudine-resistant hepatitis B virus infection. Hepatology 40(6): 1421-1425.

7. Marzella N (2006) Entecavir (baraclude) for the treatment of chronic Hepatitis B Virus (HBV) infection. P\&T 31: 313-320.

8. Gerlich WH, Robinson WS (1980) Hepatitis B virus contains protein attached to the 5' terminus of its complete DNA strand. Cell press 21(3): 801-809.

9. Hennessey K, Mendoza Aldana J, Bayutas B, Lorenzo Mariano KM, Diorditsa S (2013) Hepatitis B control in the World Health Organization's Western Pacific Region: targets, strategies, status. Vaccine 31(9): J85-92.

10. Ali M, Idrees M, Ali L, Hussain A, Ur Rehman I, et al. (2011) Hepatitis B virus in Pakistan: A systematic review of prevalence, risk factors, awareness status and genotypes. Virol J 8(102).

11. Khan F, Akbar H, Idrees M, Khan H, Shahzad K, et al. (2011) The prevalence of HBV infection in the cohort of IDPs of war against terrorism in Malakand Division of Northern Pakistan. BMC Infect Dis 11: 176.

12. Strader DB (2004) Diagnosis, management, and treatment of hepatitis C. Hepatology 39(4): 1147-1171.

13. Alter MJ, Kuhnert WL, Finelli L (2003) Guidelines for laboratory testing and result reporting of antibody to hepatitis $C$ virus. Centers for Disease Control and Prevention 52(3): 1-13.

14. Wasley A, Alter MJ (2000) Epidemiology of hepatitis C: geographic differences and temporal trends. Semin Liver Dis 20(1): 1-16.

15. Morozov VA, Lagaye S (2018) Hepatitis C virus: Morphogenesis, infection, and therapy. World Journal of Hepatology 10(2): 186.

16. Baig S, Siddiqui AA, Ahmed WU, Qureshi H, Arif A (2009) Frequency of Hepatitis C and D superinfection in patients with Hepatitis B related complex liver disorders. J Coll Physicians Surg Pak 19(11): 699-703.

17. Gretch DR (1997) Diagnostic tests for hepatitis C. Hepatology 26(3): 43S-47S.

18. Dufour DR, Talastas M, Fernandez MD, Harris B (2003) Chemiluminescence assay improves specificity of hepatitis $\mathrm{C}$ antibody detection. Clin Chem 49(6): 940-944.

19. Lee SR, Kardos KW, Schiff E, Cheryl A Berne, Karam Mounzer, et al. (2011) Evaluation of a new, rapid test for detecting HCV infection, suitable for use with blood or oral fluid. J Virol Methods 172(1-2): 27-31.

20.Williams IT, Bell BP, Kuhnert W, Alter MJ (2011) Incidence and transmission patterns of acute hepatitis C in the United States, 1982 2006. Arch Intern Med 171(3): 242-248. 
21. Duberg A, Janzon R, Bäck E, Ekdahl K, Blaxhult A (2008) The epidemiology of hepatitis C virus infection in Sweden. Euro Surveill 13(21): 18882.

22. Razali K, Thein HH, Bell J, Cooper Stanbury M, Dolan K, et al. (2007) Modelling the hepatitis $\mathrm{C}$ virus epidemic in Australia. Drug Alcohol Depend 91(2-3): 228-235.

23. Lavanchy D (2009) The global burden of hepatitis C. Liver Int 1: 74-81.

24. Lavanchy D (2011) Evolving epidemiology of hepatitis C virus. Clin Microbiol 17(2): 107-115.

25. Basit A, Kashif Rahim, Iqbal Ahmad, Mehwish Shafiqe, Sameerah Mushtaq, et al. (2014) Prevalence of Hepatitis B and C infection in Pakistan. J Inf Mol Biol 2(3): 35-38.

26. Wuytack F, Vittoria Lutje, Janus Christian Jakobsen, Karl Heinz Weiss, Paula Flanagan, et al. (2018) Sexual transmission of Hepatitis C Virus infection in a heterosexual population: A systematic review. HRB Open Research 1: 10

27. Owen R (2000) Karl Landsteiner and the first human marker locus. Genetics 155(3): 995-998.

28. Rahman M, Lodhi Y (2004) Frequency of ABO and Rhesus blood groups in blood donors in Punjab. Pak J Med Sci 20(4): 315-318.

29. Firkin F, Chesterman C, Penington D, Rush B (1989) Blood groups; blood transfusion; acquired Immune deficiency syndrome. In: De Gruchy's clinical hematology in medical practice ( $5^{\text {th }}$ Edn.)., Oxford University Press, UK, pp. 475-496.

30. Harmening MD, Firestone D (2005) The ABO blood group system. In: Harmening MN (Edt.)., Modern Blood Banking and Transfusion Practices ( $5^{\text {th }}$ Edn.)., FA Davis Company, Philadelphia, USA, pp. 108-132.

\section{ISSN: 2574-1241}

DOI: 10.26717/BJSTR.2021.35.005664

Muzafar Shah. Biomed J Sci \& Tech Res

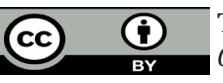

This work is licensed under Creative Commons Attribution 4.0 License

Submission Link: https://biomedres.us/submit-manuscript.php
31. Khattak ID, Khan TM, Khan P, Shah SMA, Sania Tanveer Khattak, et al. (2008) Frequency of ABO and Rhesus blood groups in District Swat, Pakistan. J Ayub Med Coll 20(4): 127-129.

32. Hoffbrand AV, P A H Moss, Pettit JE (2006) Blood Transfusion: In: Essential Haematology. Black Well Sci Publi ( $5^{\text {th }}$ Edn.)., Oxford: Blackwell Publishing, United States, pp. 307-309.

33. Bauer JD (1982) Clinical laboratory methods. In: Bauer JD (Edt.)., Mosby Company ( $9^{\text {th }}$ Edn.)., Missouri, pp. 353-376.

34. Negash M, Ayalew M, Geremew D, Workineh M (2019) Seroprevalence and associated risk factors for HIV, Hepatitis B and C among blood Donors in South Gondar District blood Bank, Northwest Ethiopia. BMC Infectious diseases 19.

35. Tunio SA, Bano S, Laghari ZA, Ali W, Waqar Ali, et al. (2013) Seroprevalence of hepatitis b and $\mathrm{c}$ among blood donors in Hyderabad, Pakistan. Gomal Journal of Medical Sciences 11(2): 220-223.

36. Arshad A, Borhany M, Anwar N, Naseer I, Ansari R, et al. (2016) Prevalence of transfusion transmissible infections in blood donors of Pakistan. BMC Hematol 16: 27.

37. Umer M, Bashir MW, Rehman R, Kiani RA (2014) Corresponding Author Frequency of $\mathrm{ABO}$ and Rh (D) Blood Groups among Blood Donors in Lahore, Pakistan. International journal of Advanced Biological and Biomedical Research 2(3): 597-600.

38. Khan N, Zalan A, Petruzziello A, Din I, Haq F, et al. (2018) Determining the Actual Prevalence of Hepatitis B in Khyber Pakhtunkhwa-Pakistan: A Meta-Analysis. The Open Virology Journal 12(1): 33-41.

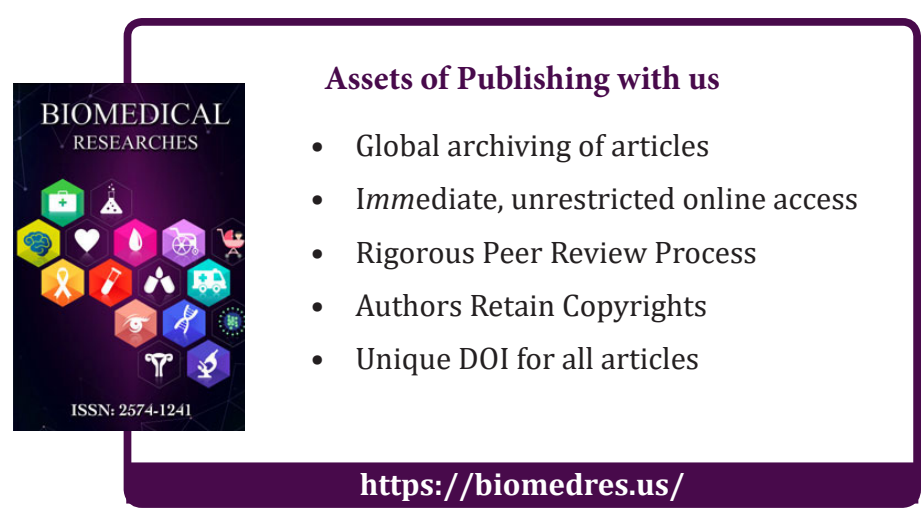

